\title{
IT Service Management Knowledge Ecosystem - Literature Review and a Conceptual Model
}

\author{
Muralidharan Ramakrishnan \\ School of Management and Enterprise \\ University of Southern Queensland \\ Toowoomba, Queensland, Australia \\ Email: Muralidharan_ram@hotmail.com
}

\section{Anup Shrestha}

School of Management and Enterprise

University of Southern Queensland

Toowoomba, Queensland, Australia

Email: Anup.Shrestha@usq.edu.au

\author{
Aileen Cater-Steel \\ School of Management and Enterprise \\ University of Southern Queensland \\ Toowoomba, Queensland, Australia \\ Email: Aileen.Cater-Steel@usq.edu.au

\section{Jeffrey Soar} \\ School of Management and Enterprise \\ University of Southern Queensland \\ Toowoomba, Queensland, Australia \\ Email: Jeffrey.Soar@usq.edu.au
}

\section{Abstract}

Information Technology Service Management (ITSM) is a customer-centric approach to manage IT Services in order to provide value to the business. The ITSM Knowledge ecosystem comprises multiple knowledge areas including process frameworks, technology tools and skills. Organisations struggle to comprehend the ecosystem due to the dynamic nature and volume of the business technology environment. A Systematic Literature Review was conducted to understand the state of the current research in ITSM knowledge ecosystem. The review indicated that the focus of the existing research is skewed towards process frameworks knowledge area and neglects tools and training. The approach proposed in the extant research fails to provide a holistic view of the ecosystem. To overcome the limitations a conceptual model is proposed based on Knowledge Commons theory.

Keywords ITSM, IT Service Management, ITSM Knowledge Ecosystem, ITIL, Knowledge Commons 


\section{Introduction}

Information Technology Service Management (ITSM) is a customer centric approach to manage IT Services in order to provide value to the business (Taylor 2007). The ITSM knowledge ecosystem comprises multiple knowledge areas including process frameworks, technology tools and skills/training. There are many stakeholders who engage in complex interactions utilising different knowledge areas. Table 1 shows the typical knowledge life cycle stages, the knowledge areas and examples of key stakeholders within the ITSM knowledge ecosystem.

\begin{tabular}{|c|c|c|c|}
\hline $\begin{array}{l}\text { Knowledge } \\
\text { area }\end{array}$ & Generation & $\begin{array}{l}\text { wledge Lifecycle Stage } \\
\text { Dissemination }\end{array}$ & Consumption \\
\hline $\begin{array}{l}\text { Process } \\
\text { frameworks }\end{array}$ & Library developers & $\begin{array}{l}\text { Professional bodies, } \\
\text { symposia, social media, } \\
\text { networks }\end{array}$ & $\begin{array}{l}\text { Organisations, } \\
\text { consultants, auditors }\end{array}$ \\
\hline Tools & Vendors, library & Marketing & Organisations \\
\hline Training/Skills & $\begin{array}{l}\text { Higher education institutions, } \\
\text { training providers, skills } \\
\text { framework }\end{array}$ & $\begin{array}{l}\text { Higher education } \\
\text { institutions, HR trainers, } \\
\text { job advertisers }\end{array}$ & $\begin{array}{l}\text { Individuals, training } \\
\text { providers, Hiring } \\
\text { Managers }\end{array}$ \\
\hline
\end{tabular}

Table 1 Key stakeholders within the ITSM knowledge ecosystem

In ITSM practice, there are many complementary process frameworks including, but not limited to, COBIT®, ISO/IEC 20000, Lean Six Sigma, Project Management Body of Knowledge (PMBOK@), PRINCE2 $\AA$, Agile, SCRUM, TOGAF®, DevOps, CMMI $\AA$ and ITIL $\AA$. Organisations often leverage more than one framework to meet their business objectives (Cater-Steel et al. 2006).

Some process frameworks have an extensive range of technology tools to support their implementation. The tools play a pivotal role in automating the process steps, integrating with other processes and providing a user interface for process execution and control.

Likewise, the process frameworks typically offer relevant skill certifications for practitioners. The certification schemes differ between process frameworks. The process frameworks, tools and skills maintain symbiotic relationships within the ITSM ecosystem.

\subsection{Research problem}

In a dynamic business technology environment, organisations need to continually look out for a complementary mix of process frameworks, supporting tools and updated skills for their employees. However, the existence of multiple process frameworks causes confusion, inefficiency and ineffectiveness (Heston and Phifer 2011). To address these issues, the research problem "Within the ITSM Knowledge ecosystem, no single platform that provides a holistic, contemporary view of all knowledge areas exists" is considered.

The research will design and evaluate a Self-Managing ITSM Knowledge Repository (SIKR). SIKR will be a useful resource for organisations during strategic planning as it provides a comprehensive view of complementary frameworks, tools and competencies. Evaluating the use of multiple frameworks within organisations is outside the scope of the research.

\section{Literature Review}

The research follows the Design Science Research (DSR) methodology (Hevner 2004) . As part of the DSR methodology, a Systematic Literature Review (SLR) is conducted to understand the current state of research knowledge. The SLR addresses the following questions:

- How is the research coverage of knowledge areas distributed?

- What are the primary techniques used to harmonise multiple process frameworks?

- Are these techniques suitable for modelling ITSM knowledge ecosystem holistically?

SLR is a structured and rigorous approach to conduct a literature review (Kitchenham et al. 2009). This research uses the SLR strategy to define the search approach, inclusion and exclusion criteria, data collection and analysis. Among the ITSM process frameworks, ITIL is the most widely adopted framework (Marrone et al. 2014). As ITIL framework spans across the entire ITSM Lifecycle, "ITIL" is used as the bridging keyword in the literature search. To cover additional relevant research papers, the 
search terms "ITSM" and "IT Service Management" are included. Table 2 shows the summary of the literature review strategy.

\begin{tabular}{ll}
\hline Criteria & Search terms \\
\hline Search keyword & (ITIL AND COBIT) OR (ITIL AND “Six Sigma”) OR (ITIL AND Lean) \\
combinations & OR (ITIL AND CMMI) OR (ITIL AND Agile) OR (ITIL AND DevOps) OR \\
& (ITSM OR IT Service Management) \\
Databases & Google Scholar, ACM Digital Library, Applied Science and Technology \\
& Source Ultimate, Business Source Ultimate, IEEE Xplore - IET \\
Language & English \\
Article type & Academic journals, Conference papers \\
Options & Scholarly (Peer reviewed) Publications, Full Text, References available, \\
& conference papers \\
Date Range & Jan 20oo to June 2018 \\
Inclusion Criteria & Papers on process frameworks with specific focus on integration/ \\
& harmonisation of multiple process frameworks \\
Exclusion Criteria & Papers outside identified process frameworks; focused on only one \\
& framework; those do not include any analysis of the overlap/integration \\
& between the process frameworks \\
\hline
\end{tabular}

Table 2 Literature review strategy

The search found 654 papers that satisfied the search criteria. The paper title and abstracts were screened reducing the set to 67 papers that discussed multiple process frameworks. Duplicate papers and papers that discussed only one framework were rejected. These 67 papers were studied to select 41 papers to be included in literature review based on inclusion criteria outlined in Table 2. The shortlisted literature comprises 15 journal articles and 26 conference papers as listed in Appendix A. To analyse the results the codification approach presented in Table 3 was followed.

\begin{tabular}{lll}
\hline Code & Description & Value \\
\hline Knowledge area & $\begin{array}{l}\text { The predominant knowledge } \\
\text { area discussed in the research }\end{array}$ & Process, skills, tools \\
Process framework coverage & $\begin{array}{l}\text { The process frameworks } \\
\text { discussed in the research }\end{array}$ & $\begin{array}{l}\text { ITIL, COBIT, CMMI, ISO, } \\
\text { DevOps, Lean, Agile, Six Sigma, } \\
\text { PMBOK }\end{array}$ \\
Process integration approach & $\begin{array}{l}\text { Approach to describe the } \\
\text { relationships between process } \\
\text { frameworks }\end{array}$ & Mapping, combination, ontology \\
\hline
\end{tabular}

Table 3 Codification approach

\section{Results and Discussion}

The knowledge areas were classified as process frameworks, tools and skills. The result indicates that 38 out of 41 included articles addressed the process framework area. The process framework research is focussed on developing a conceptual process model, a map or ontology. Only three papers discussed the issue of skills and no research was found in the tools category. The integration approaches can be broadly classified into mapping and structured ontology. Mapping is a technique of describing the relationship between related processes. Mapping was used by 23 papers to understand the relationship between process frameworks. The structured ontology provides a more formal approach to define the relationship between two entities. Pardo et al. (2013; 2012; 2014) proposed techniques for ontology mapping. The ontology-based approach would suit for process harmonisation of two to three frameworks. Since the ontological model is based on reductionist approach, it cannot harmonise large number of process frameworks due to the inability in managing large amounts of information (Mejia et al. 2016). The summary of findings to research questions is provided in Table 4.

\begin{tabular}{ll}
\hline Research question & Findings \\
\hline How is the research coverage of knowledge areas distributed? & $\begin{array}{l}92.7 \% \text { Process Frameworks, } 7 \cdot 3 \% \\
\text { Skills, o\% Tools }\end{array}$ \\
\hline
\end{tabular}




\begin{tabular}{|c|c|}
\hline iple & \\
\hline $\begin{array}{l}\text { s suitable for modelling ITSM knowledge } \\
\text { y? }\end{array}$ & hol \\
\hline
\end{tabular}

Table 4 Literature review summary

\section{Conceptual Model}

The limitations identified through the SLR include the inadequate coverage of tools and skills and inability of mapping/ontological approaches to provide a holistic view of the ITSM knowledge ecosystem. To address these limitations a fundamentally different approach is proposed based on Knowledge Commons theory (Hess and Ostrom 2007).

The term "Commons" is defined as "a general term that refers to resource shared by a group of people" (Hess and Ostrom 2007). The Commons economic theory is applied in the study of shared natural resources such as water resources, forests, fisheries, wildlife, knowledge management, and Free/opensource software (FOSS) (Macbeth and Pitt 2015). Institutional Analysis Development (IAD) Framework was proposed by Ostrom (1999) to systematically analyse the Commons. Frischmann et al. (2014) argued that the IAD framework needs to be tailored to suit knowledge commons. Drawing inspiration from IAD, this research proposes an alternative conceptual model of Knowledge Commons shown in Figure 1. The conceptual model consists of technical layer, community layer and usage layer. The technical layer is a platform for storing the knowledge artefacts. A practitioner community will contribute to the knowledge creation and governance of the repository. The usage layer will include knowledge consumers.

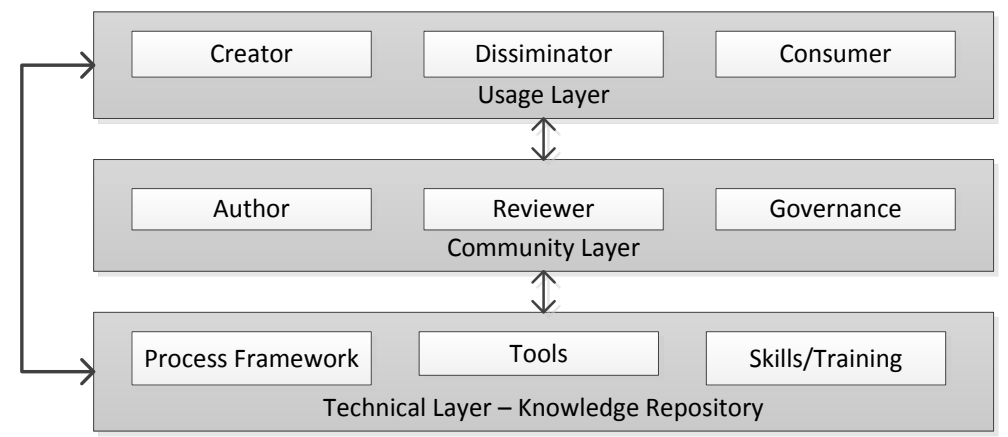

Figure 1 ITSM Knowledge Commons Conceptual Model

\section{Conclusion and Future Research Directions}

The literature review indicates that the existing research approaches fail to provide a holistic view of the ITSM Knowledge ecosystem. To overcome the limitations of the current research, a conceptual model based on Knowledge Commons is proposed. The conceptual model's practical and theoretical implications will be explored in the research. Based on the conceptual model, the research will develop a Self-managing ITSM Knowledge Repository (SIKR) using DSR methodology. The suitability and tailoring of DSR will be addressed by the research. In addition, the research will contribute to existing ITSM literature and position the results in current debate on ITSM. The research will be relevant to ITSM practitioners as SIKR is expected to provide a reliable knowledge platform.

\section{References}

Bahn, D., Betz, C., Gluhova, S., Khan, F., Lebens, M., Mosman, M., Paulson, P., Olagunju, A., Opatrny, J., Spencer, G., and Tarmizi, H. 2016. "Renewing the IT Curriculum:Responding to Agile, DevOps, and Digital Transformation." Retrieved 21/07/2018, from http://dynamicit.education/

Berrahal, W., and Marghoubi, R. 2016. "Lean continuous improvement to information technology service management implementation: Projection of ITIL framwork," 2016 International Conference on Information Technology for Organizations Development (IT4OD), pp. 1-6.

Cater-Steel, A., Tan, W.-G., and Toleman, M. 2006. "Challenge of adopting multiple process improvement frameworks," Proceedings of 14th European conference on information systems (ECIS 2006): European Conference on Information Systems, pp. 1375-1386. 
Cater-Steel, A., and Toleman, M. 2007. "Education for IT service management standards," International Journal of IT Standards and Standardization Research (5 (2)), pp 27-41.

Ehsan, N., Malik, O.A., Shabbir, F., Mirza, E., and Bhatti, M.W. 2010. "Comparative study for PMBOK \& CMMI frameworks and identifying possibilities for integrating ITIL for addressing needs of IT service industry," 2010 IEEE International Conference on Management of Innovation \& Technology, pp. 113-116.

Ekanata, A., and Girsang, A.S. 2017. "Assessment of capability level and IT governance improvement based on COBIT and ITIL framework at communication center ministry of foreign affairs," 2017 International Conference on ICT For Smart Society (ICISS), pp. 1-7.

Evelina, E., Pia, G., David, H., Liv, M.v.W., and Waldo, R.F. 2010. "Process improvement framework evaluation," 2010 International Conference on Management Science \& Engineering 17th Annual Conference Proceedings, pp. 319-326.

Frischmann, B.M., Madison, M.J., and Strandburg, K.J. 2014. Governing knowledge commons. Oxford University Press.

Heschl, J. 2008. "Mapping ITIL v3 to COBIT," COBIT Focus (1), pp 13-16.

Hess, C., and Ostrom, E. 2007. Understanding knowledge as a commons. Cambridge, Massachusetts, London, England: The MIT Press.

Heston, K.M., and Phifer, W. 2011. "The multiple quality models paradox: how much 'best practice' is just enough?," Journal of Software Maintenance \& Evolution: Research \& Practice (23:8), pp 517-531.

Hevner, A.R. 2004. "Design Science In Information Systems Research," MIS Quarterly (28:1), pp 75105 .

Huang, Z., Zavarsky, P., and Ruhl, R. 2009. "An Efficient Framework for IT Controls of Bill 198 (Canada Sarbanes-Oxley) Compliance by Aligning COBIT 4.1, ITIL v3 and ISO/IEC 27002," 2009 International Conference on Computational Science and Engineering, pp. 386-391.

Jeners, S., Lichter, H., and Pyatkova, E. 2012. "Automated Comparison of Process Improvement Reference Models Based on Similarity Metrics," 2012 19th Asia-Pacific Software Engineering Conference, pp. 743-748.

Jeners, S., Lichter, H., and Rosenkranz, C.G. 2013. "Efficient Adoption and Assessment of Multiple Process Improvement Reference Models," e-Informatica (7:1), pp 15-24.

Karkoskova, S., and Feuerlicht, G. 2015. "Extending MBI Model using ITIL and COBIT Processes," Journal of Systems Integration (1804-2724) (6:4), pp 29-44.

Kitchenham, B., Brereton, O.P., Budgen, D., Turner, M., Bailey, J., and Linkman, S. 2009. "Systematic literature reviews in software engineering-a systematic literature review," Information and software technology (51:1), pp 7-15.

Kundu, G.K., Murali Manohar, B., and Bairi, J. 2011. "A comparison of lean and CMMI for services (CMMI-SVC v1.2) best practices," Asian Journal on Quality (12:2), pp 144-166.

Kusumah, P., Sutikno, S., and Rosmansyah, Y. 2014. "Model design of information security governance assessment with collaborative integration of COBIT 5 and ITIL (case study: INTRAC)," 2014 International Conference on ICT For Smart Society (ICISS), pp. 1-6.

Latif, A.A., Din, M.M., and Ismail, R. 2010. "Challenges in Adopting and Integrating ITIL and CMMi in ICT Division of a Public Utility Company," 2010 Second International Conference on Computer Engineering and Applications, pp. 81-86.

Lin, L.-C., Li, T.-S., and Kiang, J.P. 2009. "A continual improvement framework with integration of CMMI and six-sigma model for auto industry," Quality and Reliability Engineering International (25:5), pp 551-569.

Lino, A., and da Silva, M. 2008. "Improving ITIL processes using a Lean Methodology," Instituto Superior Tecnico).

Macbeth, S., and Pitt, J.V. 2015. "Self-organising management of user-generated data and knowledge," The Knowledge Engineering Review (30:3), pp 237-264.

Marrone, M., Gacenga, F., Cater-Steel, A., and Kolbe, L. 2014. "IT service management: A cross-national study of ITIL adoption," Communications of the association for information systems (34).

McCarthy, M.A., Herger, L.M., Khan, S.M., and Belgodere, B.M. 2015. "Composable DevOps: Automated Ontology Based DevOps Maturity Analysis," 2015 IEEE International Conference on Services Computing, pp. 600-607.

Mejia, J., Muñoz, E., and Muñoz, M. 2016. "Reinforcing the applicability of multi-model environments for software process improvement using knowledge management," Science of Computer Programming (121), pp 3-15.

Năstase, P., Năstase, F., and Ionescu, C. 2009. "Challenges generated by the implementation of the IT standards COBIT 4.1, ITIL v3 and ISO/IEC 27002 in enterprises," Economic Computation \& Economic Cybernetics Studies \& Research (43:3), pp 1-16. 
Oktadini, N.R., and Surendro, K. 2014. "SLA in cloud computing: Improving SLA's life cycle applying six sigma," 2014 International Conference on Information Technology Systems and Innovation (ICITSI), pp. 279-283.

Ostrom, E. 1999. "Coping with tragedies of the commons," Annual review of political science (2:1), pp 493-535.

Pardo, C., Pino, F.J., Garcia, F., Baldassarre, M.T., and Piattini, M. 2013. "From chaos to the systematic harmonization of multiple reference models: A harmonization framework applied in two case studies," Journal of Systems and Software (86:1), pp 125-143.

Pardo, C., Pino, F.J., García, F.F.G.u.e., Piattini, M.M.P.u.e., and Baldassarre, M.T.b.d.u.i. 2012. "An ontology for the harmonization of multiple standards and models," Computer Standards \& Interfaces (34:1), pp 48-59.

Pardo, C.J., García-Rubio, F.O., Piattini- Velthuis, M., Pino-Correa, F.J., and Baldassarre, M.T. 2014. "A reference ontology for harmonizing process- reference models," Revista Facultad de Ingeniería Universidad de Antioquia), pp 29-42.

Parvizi, R., Oghbaei, F., and Khayami, S.R. 2013. "Using COBIT and ITIL frameworks to establish the alignment of business and IT organizations as one of the critical success factors in ERP implementation," The 5th Conference on Information and Knowledge Technology, pp. 274278.

Pillai, A.K.R., Pundir, A.K., and Ganapathy, L. 2014. "Improving information technology infrastructure library service delivery using an integrated lean six sigma framework: A case study in a software application support scenario," Journal of Software Engineering and Applications (7:06), p 483.

Pinheiro, M.G., and Misaghi, M. 2014. "Proposal of a Framework of Lean Governance and Management of Enterprise IT," in: Proceedings of the 16th International Conference on Information Integration and Web-based Applications Hanoi, Viet Nam: ACM, pp. 554-558.

Pirta, R., and Grabis, J. 2015. "Integrated Methodology for Information System Change Control Based on Enterprise Architecture Models," Information Technology \& Management Science (18:1), pp 103-108.

Pricope, S., and Lichter, H. 2011. "A model based integration approach for reference models," in: Proceedings of the 12th International Conference on Product Focused Software Development and Process Improvement. Torre Canne, Brindisi, Italy: ACM, pp. 6-9.

Ramachandran, R. 2013. "Capability determinants of information communications technology services (ICTS) sector: a Malaysian policy perspective," in: Proceedings of the 7th International Conference on Theory and Practice of Electronic Governance. Seoul, Republic of Korea: ACM, pp. 116-119.

Sahibudin, S., Sharifi, M., and Ayat, M. 2008. "Combining ITIL, COBIT and ISO/IEC 27002 in Order to Design a Comprehensive IT Framework in Organizations," 2008 Second Asia International Conference on Modelling \& Simulation (AMS), pp. 749-753.

Sánchez Peña, J.J., Fernández Vicente, E., and Ocaña, A.M. 2013. "ITIL, COBIT and EFQM: Can They Work Together?," International Journal of Combinatorial Optimization Problems \& Informatics (4:1), pp 54-64.

Sheikhpour, R., and Modiri, N. 2012. "An approach to map COBIT processes to ISO/IEC 27001 information security management controls," International Journal of Security and Its Applications (6:2), pp 13-28.

Stroud, R.E. 2010. "Governing and Managing the Operational Environment With COBIT and ITIL," COBIT Focus (4), pp 9-12.

Tajammul, M., and Parveen, R. 2017. "Comparative analysis of big ten ISMS standards and their effect on cloud computing," 2017 International Conference on Computing and Communication Technologies for Smart Nation (IC3TSN), pp. 362-367.

Taylor, S. 2007. "The official introduction to the ITIL service lifecycle," The Stationary Office, London).

Tshinu, S.M., Botha, G., and Herselman, M. 2008. "An Integrated ICT Management Framework for Commercial Banking Organisations in South Africa," Interdisciplinary Journal of Information, Knowledge \& Management (3), pp 39-53.

Verlaine, B., Jureta, I., and Faulkner, S. 2016. "How can ITIL and Agile Project Management coexist?," International Conference on Exploring Services Science: Springer, pp. 327-342.

Veronica, and Suryawan, A.D. 2017. "Information technology service performance management using COBIT and an ITIL framework: A systematic literature review," 2017 International Conference on Information Management and Technology (ICIMTech), pp. 150-155.

Von Solms, B. 2005. "Information Security governance: COBIT or ISO 17799 or both?," Computers \& Security (24:2), pp 99-104. 
Wickboldt, J.A., Bianchin, L.A., Lunardi, R.C., Granville, L.Z., Gaspary, L.P., and Bartolini, C. 2011. "A framework for risk assessment based on analysis of historical information of workflow execution in IT systems," Computer Networks (55:13), pp 2954-2975.

\section{Appendix A: Analysed Research Papers in SLR}

\begin{tabular}{|c|c|c|c|}
\hline Authors & Coverage & $\begin{array}{c}\text { Knowledge } \\
\text { area }\end{array}$ & Approach \\
\hline (Berrahal and Marghoubi 2016) & Lean, ITIL & Process & Mapping \\
\hline (Bahn et al. 2016) & Agile, DevOps & Skills & Curriculum \\
\hline $\begin{array}{l}\text { (Cater-Steel and Toleman } \\
\text { 2007) }\end{array}$ & ITIL, ISO/IEC 20000 & Skills & Review of skills \\
\hline (Cater-Steel et al. 2006) & ITIL, COBIT, CMMI, ISO 9001 & Process & Survey \\
\hline (Ehsan et al. 2010) & PMBOK, CMMI, ITIL & Process & Mapping \\
\hline (Ekanata and Girsang 2017) & COBIT, ITIL & Process & Mapping \\
\hline (Evelina et al. 2010) & ITIL, COBIT, CMMI, ISO 9000 & Process & Mapping \\
\hline (Heschl 2008) & COBIT, ITIL & Process & Mapping \\
\hline (Heston and Phifer 2011) & $\begin{array}{l}\text { ISO 9001:2000; Lean Six } \\
\text { Sigma; CMMI; ITIL; ISO } 27001\end{array}$ & Process & Combine \\
\hline (Huang et al. 2009) & COBIT, ITIL, ISO/IEC 27002 & Process & Mapping \\
\hline (Jeners et al. 2012) & CMMI, ITIL, COBIT & Process & Model- metrics \\
\hline (Jeners et al. 2013) & ITIL, COBIT, CMMI & Process & Integration \\
\hline $\begin{array}{l}\text { (Karkoskova and Feuerlicht } \\
\text { 2015) }\end{array}$ & ITIL, COBIT, MBI & Process & Mapping \\
\hline (Kundu et al. 2011) & CMMI, Lean & Process & Mapping \\
\hline (Kusumah et al. 2014) & COBIT, ITIL & Process & Mapping \\
\hline (Latif et al. 2010) & $\begin{array}{l}\text { ITIL, CMMI, PRINCE2, } \\
\text { PMBOK, COBIT }\end{array}$ & Process & Mapping \\
\hline (Lin et al. 2009) & CMMI, Six Sigma & Process & Combined \\
\hline (Lino and da Silva 2008) & Lean, ITIL & Process & Unclassified \\
\hline (McCarthy et al. 2015) & DevOps, ITIL & Process & Architecture \\
\hline (Mejia et al. 2016) & ITIL, COBIT, CMMI, Six sigma & Process & Mapping \\
\hline (Năstase et al. 2009) & COBIT, ITIL, ISO/IEC 27002 & Process & Mapping \\
\hline (Oktadini and Surendro 2014) & ITIL, Six Sigma & Process & Mapping \\
\hline (Pardo et al. 2012) & ITIL, ISO, CMMI, COBIT & Process & Ontology \\
\hline (Pardo et al. 2013) & CMMI, ITIL, COBIT, SWEBOK & Process & Ontology \\
\hline (Pardo et al. 2014) & $\begin{array}{l}\text { CMMI, ISO, ITIL, COBIT, } \\
\text { RiskIT }\end{array}$ & Process & Mapping \\
\hline (Parvizi et al. 2013) & ITIL, COBIT & Process & Unclassified \\
\hline (Pillai et al. 2014) & ITIL, Lean Six Sigma & Process & $\begin{array}{l}\text { Action } \\
\text { research }\end{array}$ \\
\hline (Pinheiro and Misaghi 2014) & Lean, ITIL, CMMI, COBIT & Process & Mapping \\
\hline (Pirta and Grabis 2015) & ITIL, COBIT, ValIT & Process & Combine \\
\hline (Pricope and Lichter 2011) & Generic & Process & Architecture \\
\hline (Ramachandran 2013) & $\begin{array}{l}\text { CMMI, ITIL, PMPOK, Six } \\
\text { Sigma }\end{array}$ & Skills & Mapping \\
\hline (Sahibudin et al. 2008) & ITIL, COBIT, ISO/IEC 27002 & Process & Mapping \\
\hline (Sánchez Peña et al. 2013) & ITIL, COBIT, EFQM & Process & Mapping \\
\hline (Sheikhpour and Modiri 2012) & COBIT, ISO/IEC 27001 & Process & Mapping \\
\hline (Stroud 2010) & COBIT, ITIL & Process & Mapping \\
\hline (Tajammul and Parveen 2017) & $\begin{array}{l}\text { ISO27001, PRINCE2, COBIT, } \\
\text { OPM3, CMMI, ITIL }\end{array}$ & Process & Mapping \\
\hline (Tshinu et al. 2008) & ITIL, COBIT, CMMI & Process & Combine \\
\hline (Verlaine et al. 2016) & ITIL, Agile (SCRUM) & Process & Mapping \\
\hline (Veronica and Suryawan 2017) & ITIL, COBIT & Process & $\begin{array}{l}\text { Literature } \\
\text { Review }\end{array}$ \\
\hline (Von Solms 2005) & COBIT/ISO17799 & Process & Mapping \\
\hline (Wickboldt et al. 2011) & ITIL, PMBOK, COBIT, M_o_R & Process & Combine \\
\hline
\end{tabular}




\section{Copyright}

Copyright: (C) 2018 M. Ramakrishnan, A. Shrestha, A. Cater-Steel and J. Soar. This is an open-access article distributed under the terms of the Creative Commons Attribution-NonCommercial 3.0 Australia License, which permits non-commercial use, distribution, and reproduction in any medium, provided the original author and ACIS are credited. 